\title{
The Impact of Multimedia Graphic and Text with Autistic Learners in Reading
}

\author{
Sarah Omar, Azman Bidin \\ Faculty of Creative Multimedia, Multimedia University Malaysia, Malaysia
}

Copyright (C) 2015 by authors, all rights reserved. Authors agree that this article remains permanently open access under the terms of the Creative Commons Attribution License 4.0 International License

\begin{abstract}
Autism Spectrum Disorder (ASD) refers to a groups of developmental disabilities that can cause significant social, communication and behavioral challenges . This pauses several characteristics that subject a child to problems such social communication, difficulty relating to people, things and events, and repetitive body movements or behaviors .In the academic setting as well, the learners who suffer from (ASD) encounter various problems. As an instance of academic skill reading, Reading is required to be learn but not on the way it done in traditional classroom. An intervention which yielded better results in learning reading skill, based on (Iman and Fouad, 2010) [1] organizing the memory lead to paying attention to relevant information, Thus this research, attempts to use utilize multimedia elements aimed to find out the impact of multimedia elements (graphic and text) in reading comprehension. And to ascertain how multimedia, especially graphic helps children with autism in reading comprehension. This systematic review attempts to address three specific research questions: the teaching reading comprehension to children with autism [1] can graphic with the texts help young children to improve their reading skills? [2] Can colors lead to better attention with autistic learners? [3] Does the computer-based intervention program increase and improve autistic learner's abilities to read? Results indicate that children with autism can benefit from the strategies of reading comprehension when they used graphic and text together.
\end{abstract}

Keywords Multimedia Learning, Graphic, Text, Reading Comprehension and Autism

\section{Introduction}

Both for normal and the autism children learning vocabulary is significant. In order to teach these learners especially (ASD) problem, reading comprehension skill, multimedia materials help these learners to improve their skills. Besides they gain motivation to communicate. Some researchers such as Manning-Courtney, Murray and Currans, (2013) [22] believe that Autism is a disability which lasts throughout the person's life while according to Ravindran and Myers (2012) [23] there is no cure for it. However, using intervention computer based programs and the education which is Individual Education Program (IEP) help these children progress. One of the main objectives is to help the children's to developing life skills communication in general. The educational approaches focused on knowledge and the information about the unique methods for those children with autism. learning a variety of strategies Applied Behavior Analysis (ABA) in addition the structured teaching method in the Treatment and Education of Autistic and related Communication Handicapped children (TEACCH) model and Picture Exchange Communication System (PECS) these are examples of such specially-tailored educational strategies for persons with autism. Educationally reading comprehension would be beneficial to autistic learners especially when the multimedia materials are visual movements.

\section{Materials and Methods}

Statistical procedures with systematic review for many articles were identified between 2010 and 2014 involved in multimedia elements, technologies intervention, colors and reading comprehension, computer device, mobile device Apps and computer based program. In the online scientific fields, which are related to the subject of the present study, some investigations were carried out. They included Education Resources Information Proquest, IEEEXplore and Science Direct. Including the articles were based on the 3 criteria which follow:

[1]Articles in which the focus of the study is the multimedia element e.g. graphic with text and colors in reading comprehension with autism children.[2] Articles in which the participants of the study are autistic.[3]Articles in which one dependent variable needs to be measured in order to see the multimedia elements influence on the participants. This paper was assessed separately evaluated 
based on the followings: The effect of utilizing intervention tools such as graphic with text with autistic children's reading comprehension ability, the most common strategies they make use of the colors effect on autistic children, the effect of focusing on attention and understanding as cognitive processes upon improving their skills.[1] Having interactions with computing mobile or tablets [2] Evaluating the children using pre and post-tests, [3]Using multimedia graphic with text [4] Having a groups of autistic participants.

\subsection{Analysis}

The findings provide answers of the research questions which were mentioned the evidences emphasis on multimedia elements graphic with text and colors are positive improving autism learners in reading.[1]There is a significant relationship between graphic with the text and ASD students learning result [2[There is a significant relationship between computer base program intervention increase and improve autistic learner's ability.[3]There is a significant relationship between colors effect and autism learner's attention. All the articles and studies referred to the effectiveness of multimedia elements graphic with texts and some colors with autism children reading comprehension.

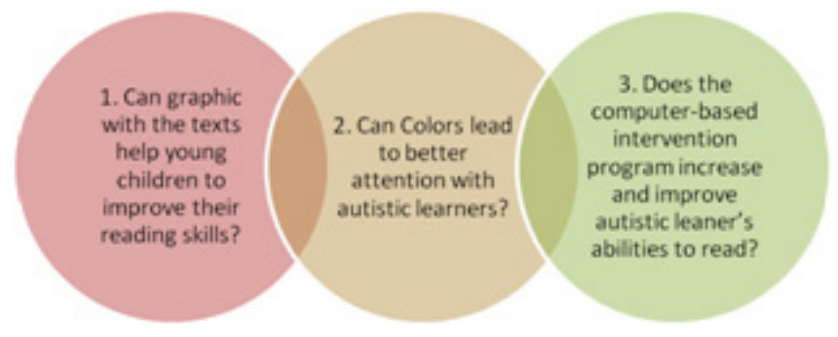

Figure 1. Relationship of the impact of graphic, color and computer programs to reading skills of autism students.

\subsection{Reading Comprehension}

Autistic ASD learners have the ability to achieved level of efficiency of learning and this is depends on the strategies and their intelligence quotient (IQ) and that are going to be used with them. Reading comprehension is referring to cognitive and linguistic process that build to identify the meaning of the word, phrases and sentence based on (Diane W Jacobs et al., 2013) [1] identify the words [2] comprehension. Reading comprehension is referring to cognitive and linguistic process that build to identify the meaning of the word, phrases and sentence .Focusing in phonetic, meaning, decoding and sound as well. Visual memory through graphic and text this facility let them recall the relative information from memory also they can identify the words by linking to the prior knowledge.(see table1)

Several studies have components of language and reading comprehension, e.g. vocabulary instruction, text comprehension and expository text. Articles were identified on reading comprehension. They emphases on the importance of used visual supporting, question-answers strategy asking questions during and after reading the text, in contrast text structure and expository text were employed and two articles were identified on vocabulary (Kim and Kim, 2012; Lin and Tsai, 2013) reading comprehension strategies instructions were provided the effective based on IEP plan and objectives added more improving in reading skills. Visual strategy during the instruction help children's with autism better to understand the task to be complete because children with autism can process visual information in additional the increasing in their attention relevant simulate task. Autistic learners do not have enough ability of inferring and responding to the questions, direct questions strategy helps them improve their skills. According to Carnahan et la., 2013)

Table 1. Summary of Research on Reading Comprehension

\begin{tabular}{|c|c|c|c|c|c|c|}
\hline Article & Participants & Sample & Component & Strategies & intervention & Outcomes \\
\hline $\begin{array}{l}\text { Flores\& Franklin } \\
\text { (2013) }\end{array}$ & $\begin{array}{c}\text { between } 8-13 \text { year } \\
\text { old }\end{array}$ & $\begin{array}{c}7 \text { under ASD } \\
\text { and } 4 \text { multiple } \\
\text { disabilities } \\
\end{array}$ & $\begin{array}{c}\text { comprehension } \\
\text { and language IEPS } \\
\text { program } \\
\end{array}$ & Direct instruction & $\begin{array}{l}\text { Direct } \\
\text { instruction }\end{array}$ & $\begin{array}{l}\text { DI programs a strong } \\
\text { had effect on } \\
\text { students learning. }\end{array}$ \\
\hline Lin, C. S. (2014) & $\begin{array}{l}\text { Thirty-five children } \\
\text { with between the } \\
\text { ages of } 4 \text { and } 6 \\
\text { Preschool Children } \\
\text { with Autism }\end{array}$ & Hyperlexia & $\begin{array}{c}\text { Reading } \\
\text { comprehension. }\end{array}$ & $\begin{array}{c}\text { multimedia } \\
\text { assessment tool } \\
\text { incorporated } \\
\text { visual } \\
\text { homographs, } \\
\text { comprehension, } \\
\text { sentence and } \\
\text { visual sentence }\end{array}$ & $\begin{array}{l}\text { Computer } \\
\text { assessment }\end{array}$ & $\begin{array}{l}\text { performed better } \\
\text { than their age } \\
\text { matched typically } \\
\text { developing peers in } \\
\text { decoding, } \\
\text { homographic and } \\
\text { visual vocabulary }\end{array}$ \\
\hline $\begin{array}{c}\text { DiGiulio, L. A. } \\
\text { (2012) }\end{array}$ & $\begin{array}{c}\text { Eight students } \\
\text { between ages of } \\
11-17 \text { years old. Five } \\
\text { of them were male } \\
\text { and three female }\end{array}$ & $\begin{array}{l}\text { High function } \\
\text { (ASD). }\end{array}$ & $\begin{array}{c}\text { multiples } \\
\text { strategies to } \\
\text { ascertain reading } \\
\text { comprehension }\end{array}$ & $\begin{array}{l}\text { Reading during } \\
\text { the classroom }\end{array}$ & $\begin{array}{l}\text { Using picture } \\
\text { with autistics } \\
\text { children }\end{array}$ & $\begin{array}{c}\text { increasing the } \\
\text { chance to reading } \\
\text { comprehension since } \\
\text { picture } \\
\text { communication } \\
\text { symbols }\end{array}$ \\
\hline $\begin{array}{c}\text { Yaw, J. S., } \\
\text { Skinner, C. H., } \\
\text { Parkhurst, J., }\end{array}$ & 12 years old boy & (ASD). & $\begin{array}{l}\text { reading } \\
\text { throughout } \\
\text { computer } \\
\end{array}$ & $\begin{array}{c}\text { Delay time } \\
\text { intervention } \\
\text { should be between }\end{array}$ & $\begin{array}{l}\text { computer } \\
\text { based }\end{array}$ & $\begin{array}{l}\text { developing their } \\
\text { reading abilities, in } \\
\text { addition developing }\end{array}$ \\
\hline
\end{tabular}




\begin{tabular}{|c|c|c|c|c|c|c|}
\hline $\begin{array}{l}\text { Taylor, C. M., } \\
\text { Booher, J., \& } \\
\text { Chambers, K. } \\
\text { (2011). }\end{array}$ & & & & $\begin{array}{l}2 \mathrm{~s} \text { and not more } \\
\text { than } 5 \mathrm{~s}\end{array}$ & & $\begin{array}{l}\text { early literacy skills is } \\
\text { thought to enhance } \\
\text { word recognition } \\
\text { read correctly within } \\
2 \mathrm{~s} \text { across lists and } \\
\text { phases }\end{array}$ \\
\hline $\begin{array}{l}\text { Zakas, Browder } \\
\quad \text { and } \\
\text { Heafner,T.(2013) }\end{array}$ & $\begin{array}{l}\text { Three students } \\
\text { Tow of them } 11 \text { and } \\
\text { one is } 13 \text { years old }\end{array}$ & (ASD) & $\begin{array}{l}\text { sight-word } \\
\text { reading }\end{array}$ & $\begin{array}{l}\text { Using vocabulary } \\
\text { maps based on } \\
\text { using a scripted } \\
\text { story-grammar } \\
\text { approach } \\
\end{array}$ & $\begin{array}{l}\text { Graphic } \\
\text { organizer }\end{array}$ & $\begin{array}{l}\text { Improved and } \\
\text { increases the } \\
\text { expository of } \\
\text { reading text } \\
\text { meaning. }\end{array}$ \\
\hline $\begin{array}{l}\text { Carnahan, Jacobs } \\
\text { Williamson(2013) }\end{array}$ & $\begin{array}{c}13 \text { individuals } \\
\text { ages } 7-13 \text { years old }\end{array}$ & $\begin{array}{c}\text { high } \\
\text { functional } \\
\text { autism, for } \\
\text { different ages } \\
\text { (pre-primer) } \\
\text { level }\end{array}$ & $\begin{array}{c}\text { reading } \\
\text { comprehension }\end{array}$ & $\begin{array}{l}\text { Contrast Text } \\
\text { Structure and } \\
\text { expository text }\end{array}$ & $\begin{array}{l}\text { computer } \\
\text { technology }\end{array}$ & $\begin{array}{l}\text { intervention was } \\
\text { very effective }\end{array}$ \\
\hline $\begin{array}{l}\text { Kim, D., \& Kim, } \\
\text { D. J. (2012) }\end{array}$ & $\begin{array}{l}\text { middle school } \\
\text { students }\end{array}$ & $\mathrm{NON}$ & $\begin{array}{l}\text { learning reading } \\
\text { vocabulary }\end{array}$ & $\begin{array}{l}3 \text { different screen } \\
\text { sizes }\end{array}$ & $\begin{array}{l}\text { Text and } \\
\text { graphic on the } \\
\text { screen }\end{array}$ & $\begin{array}{c}\text { affect not only } \\
\text { language learning } \\
\text { but also thinking } \\
\text { processes } \\
\end{array}$ \\
\hline $\begin{array}{c}\text { Carnahan, William } \\
\text { son, \& Christman, } \\
\text { (2011) }\end{array}$ & 12 years old & ASD & $\begin{array}{l}\text { reading Visual } \\
\text { Cues for (word } \\
\text { picture) }\end{array}$ & $\begin{array}{l}\text { Link to Relevant } \\
\text { Background } \\
\text { Knowledge }\end{array}$ & $\begin{array}{c}\text { computer } \\
\text { based device }\end{array}$ & $\begin{array}{l}\text { demonstrated an } \\
\text { increase in mean } \\
\text { comprehension } \\
\text { score } 100 \% \\
\end{array}$ \\
\hline $\begin{array}{l}\text { Liu, \& Breslin } \\
\text { (2013). }\end{array}$ & $\begin{array}{l}25 \text { children between } \\
3-16 \text { years } 20 \text { boys } \\
\text { and } 5 \text { girls }\end{array}$ & ASD & $\begin{array}{l}\text { visual aids picture } \\
\text { activity schedule }\end{array}$ & $\begin{array}{l}\text { under } 2 \text { protocol } \\
\text { (traditional } \\
\text { protocol and } \\
\text { picture activity } \\
\text { schedule) }\end{array}$ & $\begin{array}{c}\text { in education } \\
\text { and direct } \\
\text { attention } \\
\text { relevant } \\
\text { simulate } \\
\text { task ,perform } \\
\text { ance } 90 \% \\
\text { than other } \\
\text { groups } \\
\end{array}$ & $\begin{array}{l}\text { With visual support } \\
\text { successfully } \\
\text { performance, }\end{array}$ \\
\hline $\begin{array}{l}\text { Hanson\&McLaug } \\
\text { hlin,(2012) }\end{array}$ & 12 years old & ASD & $\begin{array}{c}\text { reading } \\
\text { comprehension } \\
\text { Direct instructor }\end{array}$ & direct (IPE) & $\begin{array}{c}\text { Computer } \\
\text { built program }\end{array}$ & $\begin{array}{l}\text { Shows that internal } \\
\text { questioning } \\
\text { improves the } \\
\text { student's } \\
\text { performance on the } \\
\text { comprehension test }\end{array}$ \\
\hline $\begin{array}{c}\text { Bethun,\&Wood.(2 } \\
\text { 013) }\end{array}$ & $\begin{array}{c}\text { Three student } \\
\text { elementary } \\
\text { levels ,two of them } \\
10 \text { years old and one } \\
8 \text { years }\end{array}$ & ASD & $\begin{array}{c}\text { reading } \\
\text { comprehension }\end{array}$ & $\begin{array}{l}\text { graphic organizers } \\
\text { graphics, } \\
\text { story/visual maps, }\end{array}$ & $\begin{array}{l}\text { questions } \\
\text { based on a } \\
\text { three-card } \\
\text { picture } \\
\text { sequence } \\
\text { visual } \\
\text { representation }\end{array}$ & $\begin{array}{l}\text { graphic organizers } \\
\text { consider as effective } \\
\text { tool }\end{array}$ \\
\hline $\begin{array}{l}\text { Dzulkifli, M. A., } \\
\text { \& Mustafar, M. F. } \\
\text { (2013) }\end{array}$ & NON & $\begin{array}{c}\text { Autism, } \\
\text { dyslexia, and } \\
\text { others } \\
\text { disabilities }\end{array}$ & $\begin{array}{l}\text { reading and } \\
\text { attention }\end{array}$ & $\begin{array}{l}\text { colored } \\
\text { multimedia } \\
\text { presentation }\end{array}$ & graphics, & $\begin{array}{c}\text { Color has the } \\
\text { potential to increase } \\
\text { chances of } \\
\text { environmental } \\
\text { stimuli }\end{array}$ \\
\hline Lin\&Tsai(2013) & $\begin{array}{l}\text { Children from } \\
\text { different ages }\end{array}$ & Hyperlexia & $\begin{array}{c}\text { visual sentence\& } \\
\text { vocabulary } \\
\text { comprehension } \\
\text { develop a } \\
\text { multi-media } \\
\text { online language } \\
\text { assessment tool } \\
\text { that presents } \\
\text { visual stimuli } \\
\end{array}$ & Homographs & $\begin{array}{l}\text { computer } \\
\text { technology to } \\
\text { develop a } \\
\text { multi-media }\end{array}$ & $\begin{array}{l}\text { Computer-assisted } \\
\text { language assessment } \\
\text { tool proved to have } \\
\text { an adequate } \\
\text { reliability and } \\
\text { validity }\end{array}$ \\
\hline $\begin{array}{l}\text { Schneps, } \\
\text { Heffner-Wong, } \\
\text { A., \& Sonnert,. } \\
\text { (2010). }\end{array}$ & 16 disabilities & ASD & $\begin{array}{l}\text { Two different } \\
\text { reading methods }\end{array}$ & $\begin{array}{l}\text { using smart phone } \\
\text { and the other one } \\
\text { reading from the } \\
\text { papers }\end{array}$ & $\begin{array}{l}\text { Using iPod } \\
\text { technology }\end{array}$ & $\begin{array}{l}\text { effective reading on } \\
\text { ipod /I phone touch } \\
\text { was positive }\end{array}$ \\
\hline
\end{tabular}




\begin{tabular}{|c|c|c|c|c|c|c|}
\hline $\begin{array}{l}\text { Oakley \& Durack } \\
\text { (2013. }\end{array}$ & 5 years old & $\begin{array}{c}\text { young } \\
\text { children with } \\
\text { autism }\end{array}$ & $\begin{array}{c}\text { Reading } \\
\text { comprehension }\end{array}$ & $\begin{array}{l}\text { ICT-enabled } \\
\text { multimodal } \\
\text { approach. }\end{array}$ & $\begin{array}{l}\text { iPads and } \\
\text { android }\end{array}$ & $\begin{array}{c}\text { supporting the } \\
\text { literacy learning } \\
\text { built strong visual } \\
\text { skill }\end{array}$ \\
\hline $\begin{array}{l}\text { Dionne, L. C., \& } \\
\text { Anderson, D. L. } \\
\text { (2013). }\end{array}$ & $\begin{array}{c}\text { children ages } 10 \text { to } \\
14,\end{array}$ & (ASD) & $\begin{array}{l}\text { teaching reading } \\
\text { comprehension }\end{array}$ & $\begin{array}{l}\text { direct instruction } \\
\text { small groups } \\
\text { instructional } \\
\text { strategies }\end{array}$ & $\begin{array}{l}\text { Assistive } \\
\text { Technology }\end{array}$ & $\begin{array}{l}\text { Effectiveness of } \\
\text { direct instruction, } \\
\text { small group } \\
\text { instruction, assistive } \\
\text { technology, and peer } \\
\text { tutoring with each } \\
\text { group of } \\
\text { participants. }\end{array}$ \\
\hline $\begin{array}{l}\text { Hill, D. A., \& } \\
\text { Flores, M. M. } \\
\quad(2014) .\end{array}$ & $\begin{array}{c}5 \text { children between } \\
\text { the ages of } 3,4 \text { and } 9 \\
\text { years old }\end{array}$ & (ASD) & $\begin{array}{l}\text { Reading prior } \\
\text { knowledge }\end{array}$ & $\begin{array}{c}\text { Graphic with text } \\
\text { PECS }\end{array}$ & $\begin{array}{l}\text { Computer } \\
\text { tablet iPad }\end{array}$ & $\begin{array}{c}\text { increased } \\
\text { independent } \\
\text { responding across } \\
\text { both interventions }\end{array}$ \\
\hline $\begin{array}{l}\text { Carnahan, C. A., } \\
\& \text { Williamson, P. } \\
\text { S. }(2013)\end{array}$ & 3 & (ASD) & $\begin{array}{l}\text { Reading and } \\
\text { comprehending } \\
\text { expository }\end{array}$ & $\begin{array}{c}\text { developed } \\
\text { three-paragraph } \\
\text { expository } \\
\text { passages } \\
\text { for all phases of } 10 \\
\text { comprehension } \\
\text { questions for each } \\
\text { of the passages }\end{array}$ & $\begin{array}{l}\text { intervention } \\
\text { was very } \\
\text { effective }\end{array}$ & $\begin{array}{c}\text { Carnahan, C. A., \& } \\
\text { Williamson, P. S. } \\
\text { (2013) }\end{array}$ \\
\hline
\end{tabular}

\subsection{Direct Method}

All roads lead to one way, the effectiveness of direct method associated with behavioral instruction lead to control their behavior and how this is important to autism children. Direct method is also used in assessment of ideas towards individuals who suffer from ASD (Flores et al., 2013) [15]Thus, In accordance with the procedures, strategies and techniques required for implementing special needs and general education in a classroom setting, direct Method of approach receives positive opinion.

\subsection{Use of Computer Technology for Teaching}

For individuals with ASD, the use of technology to provide intervention, particularly targeting the core socialcommunication deficits of the disorder is promising (Hill and Flores, 2014) [15]. However, given that the study and use of such technology programs and applications is still relatively new, the majority of the published literature is descriptive or exploratory in nature. Designing a multimedia computer based program must be Compatible with social and psychological characteristics of children for the electronic environment it is challenging for these individual therefore to build and keep the relationship between the children and technology by training them to understand how to use technology therefore, there is no defect in the process of receiving information from the computer during a lesson because the compatibility between the classroom environment and education about ways computer must be complementary to the each oother. (see table 2)

Table 2. Summary of Research on Computer Intervention Tools

\begin{tabular}{|c|c|c|c|c|c|c|}
\hline Article & Participants & Sample & Component & Strategies & intervention & Outcomes \\
\hline $\begin{array}{c}\text { Pavlov, N. } \\
(2014)\end{array}$ & non & (ASD) & $\begin{array}{c}\text { Open Book, a reading } \\
\text { assistive }\end{array}$ & $\begin{array}{c}\text { Computer technology design } \\
\text { interface assisting tool }\end{array}$ & $\begin{array}{c}\text { Positive feedback } \\
\text { with autism } \\
\text { learners }\end{array}$ \\
\hline $\begin{array}{c}\text { Mintz, J. } \\
(2013)\end{array}$ & 26 children & ASD & $\begin{array}{c}\text { Computer mediated } \\
\text { communication }\end{array}$ & mobile ICT's potential & $\begin{array}{c}\text { Hand prototype } \\
\text { smartphones } \\
\text { successfully } \\
\text { finished their task } \\
\text { of hand prototype }\end{array}$ \\
\hline $\begin{array}{c}\text { Artoni, \& } \\
\text { Senette, } \\
(2013)\end{array}$ & $\begin{array}{c}\text { two and ten } \\
\text { years old }\end{array}$ & ASD & $\begin{array}{c}\text { ABA-based } \\
\text { interventions }\end{array}$ & $\begin{array}{c}\text { design of the user interface } \\
\text { (UI) }\end{array}$ & $\begin{array}{c}\text { Mobile } \\
\text { technology, } \\
\text { Android }\end{array}$ & easy of interaction \\
\hline $\begin{array}{c}\text { Khowaja, \& } \\
\text { Salim(2013) }\end{array}$ & non & non & Systematic review & $\begin{array}{c}\text { method graphic with the text } \\
\text { in cooperate with strategy } \\
\text { Computer-based } \\
\text { intervention }\end{array}$ & $\begin{array}{c}\text { is very promising } \\
\text { and significant } \\
\text { improving in } \\
\text { learning } \\
\text { performance }\end{array}$ \\
\hline
\end{tabular}


Table 3. Summary of Research on Multimedia

\begin{tabular}{|c|c|c|c|c|c|}
\hline Article & Participants & Sample & Component & Strategies & intervention \\
\hline Coffindaffer, K. C. C. (2010). & non & (ASD) & $\begin{array}{c}\text { Multimedia principles } \\
\text { text and image }\end{array}$ & $\begin{array}{c}\text { theoretical rational that when } \\
\text { pictures and words are } \\
\text { presented together,Text on } \\
\text { the computer how should the } \\
\text { text and image should be }\end{array}$ & $\begin{array}{c}\text { increasing learner's } \\
\text { understanding of the } \\
\text { material }\end{array}$ \\
\hline Khowaja, \& Salim(2013) & non & non & Systematic review & $\begin{array}{c}\text { method graphic with the text } \\
\text { in cooperate with strategy }\end{array}$ & $\begin{array}{c}\text { Computer-based } \\
\text { intervention }\end{array}$ \\
\hline $\begin{array}{c}\text { Dr, Vickii Jenvey and } \\
\text { GeorgeButterworth(2014) }\end{array}$ & $2-7$ year old & $\begin{array}{c}\text { Normal } \\
\text { children }\end{array}$ & $\begin{array}{c}\text { Piaget is that } \\
\text { intellectual } \\
\text { development }\end{array}$ & $\begin{array}{c}\text { developing cognitive by } \\
\text { structure of the mind }\end{array}$ & Pre-school \\
\hline
\end{tabular}

\subsection{Computer Based Programs}

Understand the affect multimedia element and how to interact with technology. Technology help autism to interact with the course content appropriately to reflect learning context, and provide more relevant information to meet the dynamically changing .Learning context contain highly context -sensitive activities computer learning within new technologies autism should be able to explore much more knowledge through help of context awareness and user interface integration with multimedia elements increased and develop the understanding of the information's flow, according to Mayer theory how learning can be done through computer technology devices ( Clark and Richard, 2011) due to the strategies of computer based program intervention which were used in various studies of this review are as follows: (Hayes and Yeganyan, 2010; Artoni and Senette, 2013;Fletcher and Watson, 2014) multimedia presented visual interactive program based on computer it is stimulus and reflect cognitive processing. Visual material provides the understanding as well as visual attention. This happens during the content which is shown on screen with clear image, suitable fonts and colors. There are several ways for comprehension instruction strategies and five vocabulary instruction strategies (Khowaja and Salim, 2013) two strategies e.g. multimedia methods and explicit instruction out of five vocabulary instruction strategies were shown to be used more than the other 3 . Text comprehension instruction strategies, one of them e.g. question answering strategy was found to be more commonly used than the other six strategies. (See table3)

According to the results, reading comprehension strategies and the use of technology were beneficial for the autistic learners. Autistic children can easily lose their concentration and attention to something. But which strategy is better used with these children using the pictures first and then the words or using the words first and then the pictures, based on findings of the studies teachers can choose one of these strategies based on the previous knowledge of the learners and also their Intelligence Quotient (IQ). These are what they need to be taken into account when one wants to prefer one strategy over the others (Coffindaffer, 2010; Clark and Mayer, 2011; Eitel and Scheiter, 2014).

\subsection{Colors Effective}

[13] Dzulkifli and Mustafa, (2013) focused on playing significant roles in attracting attention and influencing memory the possibility of colors to increase chances by stimuli environmental to be encoded, stored, and retrieved successfully, the reviewing on colors attention from the small screen to help learners to reading comprehension (Biggam and Simmons, 2011; Lee and Obinata, 2013; Plass and Um, 2014) colored are often used in everyday life, in images and navigation icons. Autistic learner are visual they can decode colored before language. Autism children are more looking to the colored than the shapes, Colors such as yellow, blue and green or color overlay are used in cognitive theory of multimedia which has been proven to be effective in improving reading and attention accuracy.

With the aim of decreasing behavioral terms, white can be used as the background color and black can be used as the font colors .Great performance were observed with autistic children when red, green and yellow colors are used together with multimedia image and words as well using natural colored would help autism with their live in general such as social interaction and decoding situation. Adele,(2014) colores image or pictures are useful steps to attract their attention and gave them approximation for the meaning to the whole idea that going to be for contents should be simplified images. 


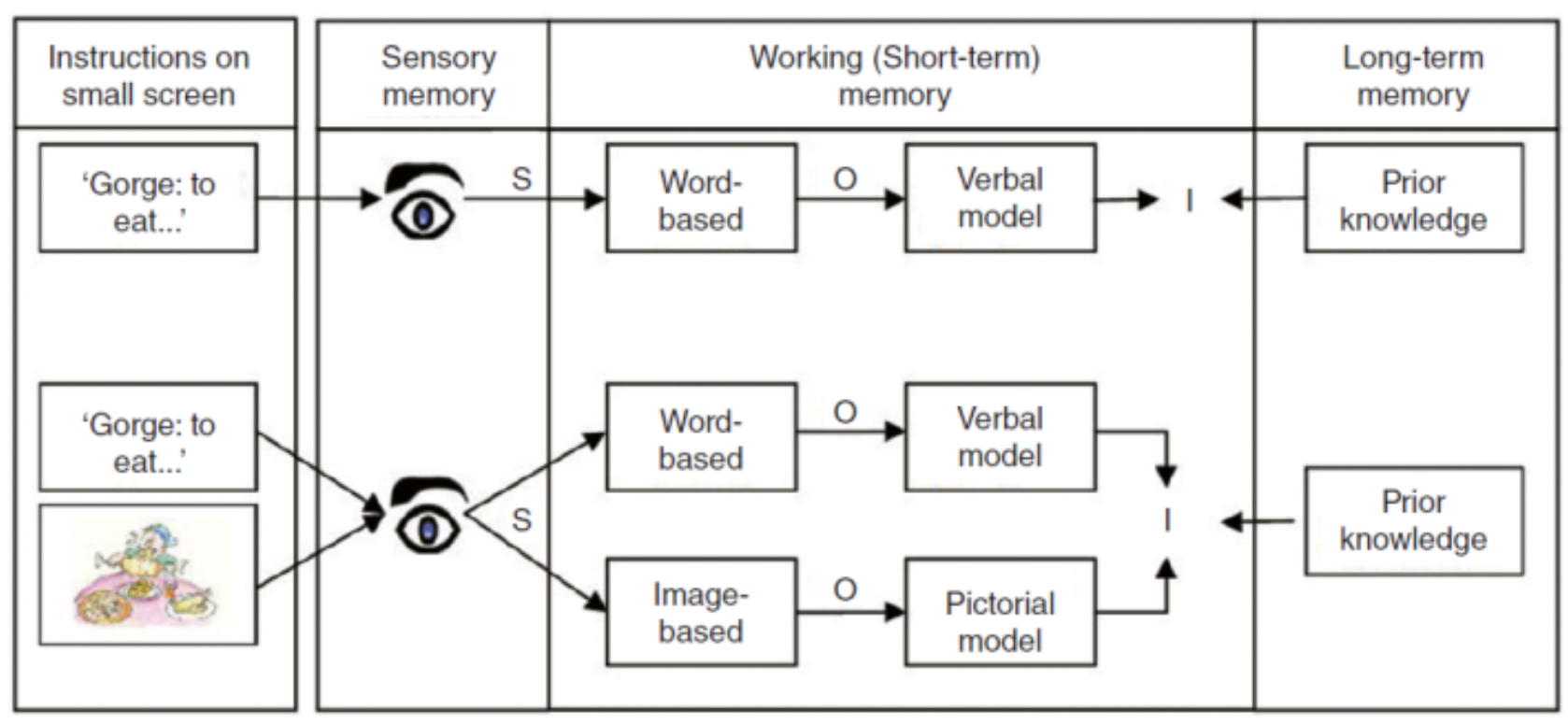

Figure 2. Framework of small screen for learning

\subsection{Graphic and Text Effects}

Visual supports are essential for individuals with autism, but getting the right visual can involve a combination of strategy and creativity. According to the rules of studies which investigated the impact of the sequence of presenting text and pictures on the computer screen choosing which one should be present first pictures or the texts depends on the learners previous knowledge. Multimedia has defined roles in how it should be done since the learners are from disabilities category. When pictures and texts were used together with autistic children, the size of the fonts needs to be between 10 and 14. On the other hand, the font size of 16 is essential when the words comes alone with no accompanying pictures are used the size range of certain fonts between 12 to 14 point. Being good examples of rounded fonts which have enough space between letters, the appropriate font types can be Arial, Comic Sans, Verdana, Helvetica, Tahoma, or Trebuchet. With regards to the size of the screen it was identified that the learners who were instructed using larger screens did better in comprehending material than those whom with smaller font sizes on computer screens. This study has been investigated based on the impact of multimedia, specially (graphic, text) in teaching young children with autism to improve their reading skills and to find out the relationship between the colors and new technology such as tablets (android and iPad) increase and improve autistic learner's abilities to read The author examine the effect of multimedia on autistic children learners although they have many different characteristics, the results have shown that efficiency of new innovation technology and multimedia are considerable important for special disabilities. The new expression has been used in the field of computer intervention with disabilities (treatment technology) education via computers. Due to facilities that it have in many aspects such as size, easy to use and interact with the learners in addition touch feature that adds large interaction between students and computers. Particularly with the disabilities who are using new technologies they prefer to starts in early ages training them on how to use it .Using multimedia elements should be stared form early stages between pre-school and elementary.

\subsection{Language}

ASD children usually have impaired or delayed language APA,(2000) according to national research council,(2001) the development of communication skills which are both verbal and nonverbal have been the most important concern of the interventions for the ASD children. Language depend on the ability to reading oral language, correct pronunciation and decoding words oral language contribute in development vocabulary consequently reading with ASD learners. i.e. supporting educational contexts with text and graphics indicator to learner to understand meaning thus comprehension what they had been reading, especially high function disabilities (HFD) hyperlexia their abilities are advanced in decode symbols and words without understanding meaning of the written text.

On the other hand, based on the findings when teachers wanted to teach the reading properly they have to consider three things that cannot be separated from each other oral language ability on the proper pronunciation, grammar and accuracy vocal apparatus, it is difficult for ASD learners to learn reading comprehension skill. These learners have various deficits which include Linguistic communication and cognitive processing deficits. Learning reading comprehension for autistic children who had strength and weakness high-functioning or a Asperger's Syndrome individuals are dissimilar in intellectual ability average, language and reading can affect by syntax and semantics in reading comprehension (Inoue, Wada, Natsuyama, Kamitani, and Miyaoka , 2014). 


\section{Conclusions}

One of the most important processes that involved in the effectiveness on reading from text is to understand and identify each words Indeed, often the problem deficits associated with the decoding require effortful most of the reader's children who suffer from this problem their ability to read are limited and it is depends on the processing voice and correct pronunciation of the letters And therefore there is a close correlation between reading and phonological processing Brown, Oram-Cardy and Johnson, (2013) computer based intervention (CBI) in the treatment of autism spectrum disorders (ASD) offer better advantages to traditional one-to-one and traditional classroom teaching easier to reduce distractions and the incorporation of an individual's relative visual learning strengths .According to the studies use multimedia with autistic learners can be improved and developing their reading comprehension skills. Multimedia have some role which are the used of (graphic and text) elements depends on the learners' background or previous knowledge decides whether the picture or the text must be presented first. i.e. if the learners have some information about the subject in this is case must use or received graphic or graphic after the text, but if they don't have low knowledge in this case must use picture before text Eitel and Scheiter, (2014) found presenting picture and text in an irregular manner is not as much influential as presenting them sequentially. In addition, based on previous study multimedia principle emphasized the role of theoretical rationale that the connection between pictures and words when presented together learners can build mental models when the information cut into small parts Coffindaffer, (2010) the font size should be 14 point and the background color contrast for example (dark print on light paper) according to use multimedia material can lead to accomplishment result in reading improvement with personalize the interface according to their abilities Pavlov, (2014) based on the review has been done It have been found that text and graphic-using principles on the computer screens. They have also mentioned the elements which are necessary to the educators those who planning to use computer devices based program with multimedia presentation available in market for all the disabilities in general. None of the previous studies has applied multimedia principles (Kim and Kim, 2012; Pavlov, 2014; Eifel and Scheiter, 2014) based on founding colors have great impact perspective on the learners autistic in particular because of their highly visualization peculiarity. Colors have powerful influence enhancing memory performance with them designing multimedia interface is request to build up application computer based program (CBP) in appropriate way can suit their special needs as autistic disabilities. Autistics are very sensitive to certain colors they make highly respond such as (blue, dark yellow and green) these colors work as a positive effect have motivated them. Colors are strong positive and there are strong relationship between visual design shapes and colors, colors affected on learners when the multimedia include face features like laugh and sadness (Plass .et al, 2014) learners can be sustained throughout the learning tasks. According to the findings of the present study, future studies need to consider how assistive technologies can support and challenge students at the same time. By joining some of the physical interventions' engaging features with the configuration and recordkeeping which are simplified and inherent to technological tools, it is possible to create new applications which make use of ubicomp technologies such as smart phones devices and tangible interfaces. This study is about the impact of multimedia (graphic with text) on autistic learner in reading comprehension. Carrying out the effective of using multimedia elements implement with new technology tablet and Smartphone's treatment technology, visual supports which is came with different terminology such as graphic organizer, anchor chart and visual maps . The author believed that the tools which have been specially designed for special needs associate with education can possibly to use traditional classrooms and they can have full advantage of using multimedia Therefore, although the results have been found achieved based on the study on the autistic children who are not very good in verbal communication, they can be useful for other children and other disabilities in general as well. Reading process is not an easy process for both on normal and autistic children, because of the defect in the mental capacity and duration that they need to learn how to read and reading comprehension may take long times than normal children does. Learning reading starts from early school age, learning reading defined on how to decoding words. There are many strategies and techniques have been defined by many other researchers implement. Direct instruction one of most important method have been used with autistic learner in additional loaves has emphasis on how is it important to autistic. The evidence supports the effectiveness of using computer based intervention to teaching reading comprehension to children with autism. Applied technology with the aim to providing better education to the autistic children and young people supporting autistic education curriculum or individualized education programming with the use of modern technologies methods, especially according to their disabilities and fitting their own needs.

\section{REFERENCES}

[1] Alshami, Ali Waffa .Cure Autism pedagogical methods, psychological and medical (2004)

[2] http://www.autism.net.au.Americanpsychiatric Association 2012.

[3] Aliee, Z. S., Jomhari, N., Rezaei, R., \& Alias, N. Facilitating Autistic Children's Split Attention in Designing Computer Teaching Instructions. Life Science Journal, 10(3). (2013).

[4] Biggam, C. P., Hough, C. A., Kay, C. J., \& Simmons, D. R. 
(Eds). New directions in colour studies. John Benjamins Publishing). (2011).

[5] Carnahan, C. A., \& Williamson, P. S. Does Compare-Contrast Text Structure Help Students With Autism Spectrum Disorder Comprehend Science Text? Exceptional Children, 79(3), 347-363. (2013).

[6] Carnahan, C. R., Williamson, P. S., \& Christman, J. Linking cognition and literacy in students with autism spectrum disorder. Teaching Exceptional Children, 43(6), 54-62. (2011),

[7] Clark, R. C., \& Mayer, R. E .E-learning and the science of instruction: Proven guidelines for consumers and designers of multimedia learning. John Wiley \& Sons. . (2011).

[8] Coffindaffer, K. C. C.Text, graphics, and multimedia materials employed in learning a computer-based procedural task (pp. 1-267). West Virginia Universit Libraries. (2010).

[9] Devine Adele. Colour Coding for Learners with Autism A Resource Book for Creating Meaning through Colour at Home and School, (2014).

[10] Diane W. Jacobs, Amanda L. Richdaleb, Predicting literacy in children with a high-functioning autism spectrum disorder,Volume 34, Issue 8, August 2013, Pages 23792390.(2013).

[11] DiGiulio, L. A Curriculum Project: Reading Comprehension for First Grade Readers with Autism (Doctoral dissertation, State University of New York). (2012)

[12] Dionne, L. C., \& Anderson, D. L. Effective Instructional Strategies To Teacher And Skill To Students with Autism Spectrum Disorder In Elementary General Education Classroom. (2013).

[13] Dzulkifli, M. A., \& Mustafar, M. F.The influence of colour on memory performance: A review. The Malaysian journal of medical sciences: MJMS, 20(2), 3. (2013).

[14] Eitel, A., \& Scheiter, K.Picture or Text First? Explaining Sequence Effects when Learning with Pictures and Text. Educational Psychology Review, 1-28. (2014)

[15] Flores, M. M., Nelson, C., Hinton, V., Franklin, T. M., Strozier,
S. D., Terry, L., \& Franklin, S. Teaching reading comprehension and language skills to student with autism spectrum disorder and development disabilities using direct instruction. (2013) .

[16] Grynszpan, O., Weiss, P. L. T., Perez-Diaz, F., \& Gal, E., Innovative technology-based interventions for autism spectrum disorders: A meta-analysis. Autism, 18(4), 346-361. (2014)

[17] Khowaja, K., \& Salim, S. S. A systematic review of strategies and computer-based intervention (CBI) for reading comprehension of children with autism. Research in Autism Spectrum Disorders, 7(9), 1111-1121. doi:10.1016/j.rasd.2013.05.009 (2013)

[18] Kim, D., \& Kim, D. J.Effect of screen size on multimedia vocabulary learning. British Journal of Educational Technology, 43(1), 62-70. (2012),

[19] Lin, C. S., Chang, S. H., Liou, W. Y., \& Tsai, Y. S. The development of a multimedia online language assessment tool for young children with autism. Research in developmental disabilities, 34(10), 3553-3565. (2013)

[20] Liu, T., \& Breslin, C. M. The Effect of a Picture Activity Schedule on Performance of the MABC-2 for Children with Autism Spectrum Disorder. Research quarterly for exercise and sport, 84(2), 206-21(2013).

[21] Whitcomb, S. a., Bass, J. D., \& Luiselli, J. K. Effects of a Computer-Based Early Reading Program (Headsprout $\left.{ }^{\circledR}\right)$ on Word List and Text Reading Skills in a Student with Autism. Journal of Developmental and Physical Disabilities, 23(6), 491-499. doi:10.1007/s10882-011-9240- (2011).

[22] Manning-Courtney, P., Murray, D., Currans, K., Johnson, H., Bing, N., Kroeger-Geoppinger, K. \& Messerschmidt, T.Autism spectrum disorders.Current problems in pediatric and adolescent health care, 43(1), 2-11(2013).

[23] Ravindran, N., \& Myers, B. J. Cultural influences on perceptions of health, illness, and disability: A review and focus on autism. Journal of Child and Family Studies, 21(2), 311-319. (2012). 